\title{
A Comparative Study of Gut Enzymes and Nest Materials of Three Mound Building Termites of Eastern India
}

\author{
Satarupa HOTA ${ }^{1} \quad$ Sunanda SAHOO ${ }^{2 *}$ \\ 1,2School of Life Sciences, Sambalpur University, JyotiVihar, Burla - 768019, Odisha, INDIA \\ e-mails: ${ }^{1}$ satarupahota369@gmail.com, ${ }^{2 *}$ drsunanda_sahoo@yahoo.com \\ ORCID IDs: ${ }^{10000-0001-6761-2181, ~}{ }^{2 *} 0000-0002-1934-8133$
}

\begin{abstract}
Termites are found to digest a wide variety of lignocellulosic biomass including wood with high lignin content by the aid of unique cellulolytic and hemicellulolytic microorganisms. A research gap is realized in works associated with termite gut enzyme activities in India. Therefore, the present work is focused on the comparison of termite gut enzyme activities among epigeous, subterranean, arboreal termites and the physicochemical properties of respective mound soils collected from Sambalpur University Campus, Odisha, India. The mound building termites (subterranean and epigeous) showed significantly more cellulase, xylanase and phosphatase enzyme activities than the arboreal termites. The enzyme activities showed efficient correlation with organic carbon, total nitrogen, available potassium and water holding capacity of respective mound materials. This particular study has provided new information regarding the contribution of three distinct termite species towards soil fertility status. Further, a high quantity of nutrients accumulated in subterranean termite mound soils along with high enzyme activities by subterranean species, $O$. obesus in the current study, can be considered a hotspot for microbial concentration, which can be exploited for biofuel production, and mound soil as soil amendment, bioremediation and bio-filtration purpose.
\end{abstract}

Key words: Termites, termite gut enzymes, termite gut microbes, mound soil, physiochemical properties, microbial concentration.

Hota, S. \& Sahoo, S. (2021). A Comparative study of gut enzymes and nest materials of three mound building termites of Eastern India. Journal of the Entomological Research Society, 23(3), 187-196. 
HOTA, S., SAHOO, S.

\section{INTRODUCTION}

The termites hold a vital status as a primary consumer and contribute in many ways in tropical ecosystems. They are involved in increasing soil fertility by disintegrating wood in its many forms and thereby enhancing the plant growth. Insects like the termites have the unique ability to digest lignocellulose with high efficiency and often using it as a sole food source. Termites can digest $74-99 \%$ lignocelluloses (Ni \&Tokuda, 2013). Earlier studies also indicated that novel enzymes with high lignocellulose degradation potential may reside in termite guts. It is well documented that in tropical ecosystems, termites are among the most important soil invertebrate groups for playing an essential role in decomposing processes, nutrient cycling, and changes in soil properties. Cellulose is the basic food requirement for all termites and it is found in all types of plant-based materials. The cellulose is digested by bacteria in the gut of species in the family Termitidae (Slaytor, 2000).

Most termite species eat ground growths, and have an important role in maintaining soil fertility. The plant tissues on which termites feed contain very little protein and therefore have little nitrogen. Gut bacteria are also used by some termites to regulate the nitrogen in the atmosphere. In addition to cellulose, termites are able to degrade other glucose polymers such as starch and glycogen through the action of amylases (Waller \& La Fage, 1987).

The symbiotic gut floras of termites are able to degrade huge mass of wood constituents such as cellulose and hemicelluloses (Schäfer et al, 1996). Termites breaks down lignocelluloses by their own enzymes along with those of symbiotic gut microflora (Brune, 2014). The linear polysaccharide $\beta-1,4-x y l a n$ of hemicellulose, a major component of the plant cell wall is degraded into simple xylose by xylanase enzyme (Beg et al, 2001; Lima et al, 2014), cellulases (endoglucanase, exoglucanase, and $\beta$-glucosidase), hemicellulases ( $\beta$-xylosidase, $\alpha$-l-arabinofuranosidase, and $\beta$-d-xylanase), $\alpha$-amylase, and proteases (trypsin-like, chymotrypsin-like, and keratinase-type) in gut extracts from Nasutitermes corniger workers and soldiers.

The termite mound with its extensively accumulated nutrients is considered as a 'gold mine' for bacterial clusters (Enagbonma \& Babalola, 2019). However, over the years, not much attention has been given to the bacteria present in termite mound soil particularly in India. This is because many studies have focused on approaches to manage termites which they see as a menace to crops and buildings.

The termite gut and its mound soil create well defined ecological environment causing the development of a special group of cellulolytic and hemicellulolytic microorganisms (Varma, Kolli, Paul, Saxena, \& Konig, 1994). The mound building termites of the genus Odontotermes support rich microbial biomass as reported by several authors. However, there was a paucity of literature on termite gut enzyme activities particularly in Odisha, India. Hence, the present work was aimed to study the gut enzyme activities of three phytogeophagus and mound building termite species namely, Odontotermes brunneus (Hagens, 1858) from the roadside area, Odontotermes obesus from the subterranean mound of grassland site and 
A Comparative Study of Gut Enzymes and Nest Materials of Three Mound Building Termites

Odontotermes feae (Wasmann, 1896) from the arboreal nest. The study also included physicochemical properties of respective termites mound soil.

The significance of the study lies in the fact that xylophagous termites are capable of degrading lignocellulose by symbiotic gut microorganisms along with the host's indigenous enzymes and it is believed that the termite gut with rich microbial community might probably help to obtain natural yeasts with celluloytic, xylanolytic and ethanologenic traits required for bioethanol production from lignocellulosic biomass. Therefore, the present work was carried out to observe the gut enzyme activities of three native termites as a pioneer study in Western Odisha.

\section{MATERIALS AND METHODS}

\section{Termite collection and identification}

The termites were collected from six roadside small epigeous mounds, from six underground/ subterranean galleries of grassland sites, and from the galleries on the surface of six mango trees of Sambalpur University Campus (Figs.1-4). They were then sent to ZSI (Zoological Survey of India), Kolkata for species identification. The termites collected from the trap or mounds were washed thoroughly by tap water to remove soil particles and were then washed with distilled water. The clean termites were then air-dried, stored in ethanol at $5-6^{\circ} \mathrm{C}$ until dissection.
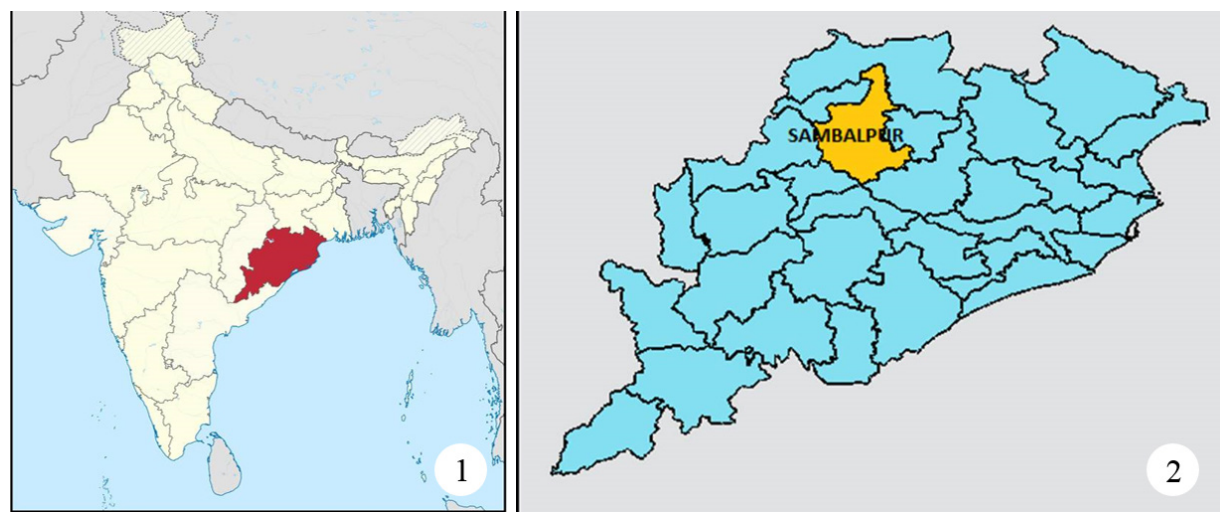

Figs. 1,2. 1. Political map of India highlighting the state Odisha. 2. Political outline map of the state Odisha and highlighting the district from where the samples were collected. (Sahu, Nayak, \& Sahu, 2020; District Administration Sambalpur, 2021).

\section{Termite gut removal}

The termites were dissected by following the method adopted by Smith (2007). The termites were removed from freeze, kept on ice; their guts were dissected and removed using surgical blade and forceps, further dipped in Sodium acetate buffer. The gut parts were then manually homogenized in chilled glass motor and pestle with $1 \mathrm{ml}$ acetate buffer. The homogenization was done by taking 50 termite gut materials/ $\mathrm{ml}$ of acetate buffer from a pool of approximately 500 termites and kept on ice until enzyme extraction was done. 
HOTA, S., SAHOO, S.

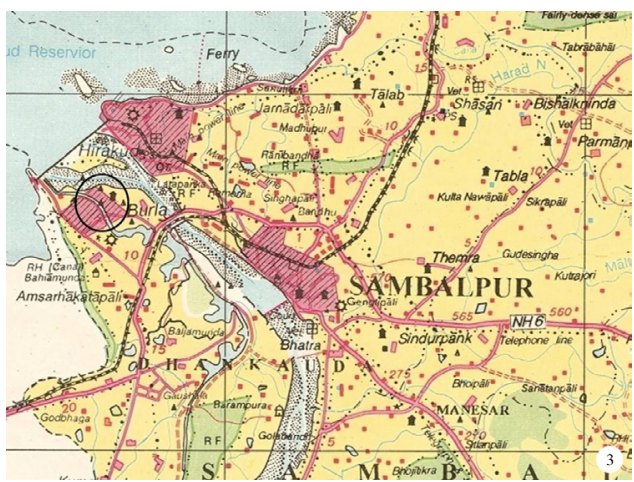

Fig. 3. General reference map of sambalpur district with a black outline of the study sites (Mehta, 1996).

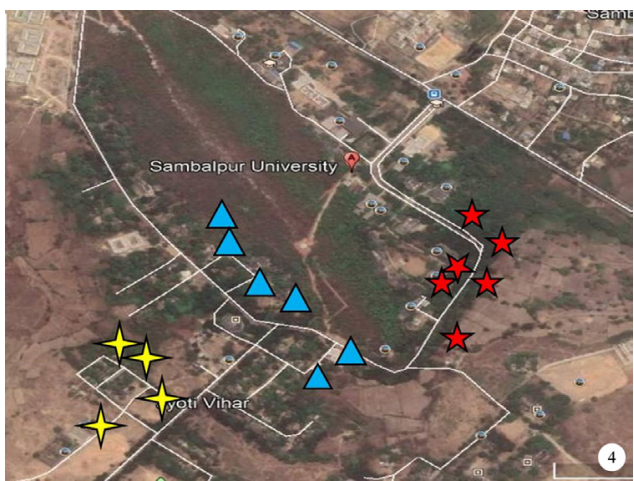

Fig. 4. Study sites: $(\downarrow$ ) Subterranean galleries of grassland, ( $\star$ ) From six epigeous mound of road side, $(\Delta)$ From the galleries on the surface of six mango trees of Sambalpur University Campus (Keyhole, Inc., 2001).

\section{Termites gut enzyme extraction and assay}

The homogenate extract containing termite gut contents of each eppendorf tube was then centrifuged at $14,000 \mathrm{rpm}$ at $4^{\circ} \mathrm{C}$ for 15 minutes with the help of a cold centrifuge, (REMI C-30). The supernatants were collected, frozen, and kept at $-80^{\circ} \mathrm{C}$ until used in enzyme assays. The extracts in sodium acetate buffer were used in assays for cellulase, xylanase, $\alpha$-amylase, and phosphatase activities. Cellulase and xylanase activity was studied as per Smith (2007).

\section{Cellulase activity}

For cellulase assay, the substrate solution used was $0.1 \%$ CMC (Carboxy Methyl Cellulose) prepared in sodium acetate buffer $(\mathrm{pH} 5.5,0.1 \mathrm{M})$. The solutions were slightly heated until CMC particles were no longer visible. Then the solution was used as a substrate for enzyme assay. In the sample tubes $1.8 \mathrm{ml}$ of CMC solution were taken and $200 \mu \mathrm{l}(0.2 \mathrm{ml})$ of enzyme extract was added. The enzyme-substrate 
A Comparative Study of Gut Enzymes and Nest Materials of Three Mound Building Termites

solutions were then allowed to react for 10 mins at room temperature. Whereas, an equal amount of acetate buffer and enzyme extract was taken in a blank tube i.e. without substrate solution. After the enzyme-substrate reaction, $2 \mathrm{ml}$ of 2, 4 DNSA (2, 4-Dinitro salicylic Acid) was added in all three test tubes. And immediately after the addition of DNSA, the test tubes were then placed in a boiling water bath to induce the oxidation-reduction reaction and the amount of glucose formed was determined spectrophotometrically at $540 \mathrm{~nm}$. The cellulase activity was expressed in terms of $\mu \mathrm{g}$ glucose/ml of enzyme extract/ minute.

\section{Xylanase activity}

For xylanase assay, the substrate solution was $0.01 \% \mathrm{D}$-Xylose prepared in the same sodium acetate buffer. The solution then slightly heated until Xylan particles were no longer visible. The solution was then used as a substrate for the enzyme assay. Xylanase assays were conducted in three glass test tubes, one as blank and the other two sample tubes. In each tubes $200 \mu \mathrm{l}(0.2 \mathrm{ml})$ of enzyme extract were taken. Then $1.8 \mathrm{ml}$ of xylan solution was added in sample tubes while the blank test tube the same amount of acetate buffer was added. After 10 mins of enzyme-substrate reaction, $2 \mathrm{ml}$ of 2, 4 DNSA was added in all three test tubes. And immediately after the addition of DNSA, the test tubes were then placed in a boiling water bath for 5 minutes to induce the oxidation-reduction and the amount of glucose formed was determined spectrophotometrically at $540 \mathrm{~nm}$. The xylanase activity was expressed in terms of $\mu \mathrm{g}$ glucose $/ \mathrm{ml}$ of enzyme extract/ minute.

\section{$\alpha$-Amylase activity}

The assay was carried out based on the method described by Bernfeld (1955). Gut extract from termites was incubated at $50^{\circ} \mathrm{C}$ for $10 \mathrm{~min}$ with $400 \mu \mathrm{l}$ of $1 \%(\mathrm{w} / \mathrm{v})$ soluble starch in $0.1 \mathrm{M}$ sodium acetate $\mathrm{pH} 5.5$ containing $0.02 \mathrm{M} \mathrm{CaCl}_{2}$ and $0.15 \mathrm{M}$ $\mathrm{NaCl}$. The reaction was stopped by adding $500 \mu \mathrm{l}$ of DNSA. Next, the assays were heated at $100^{\circ} \mathrm{C}$ in boiling water for 6 min and immediately cooled on ice for $15 \mathrm{~min}$. Then, absorbance was measured at $540 \mathrm{~nm}$. The amount of reducing sugars was determined using the calibration curve of glucose. Reaction blanks were performed without starch or without extracts. The amylase activity was expressed in terms of $\mu \mathrm{g}$ glucose $/ \mathrm{ml}$ of enzyme extract/ minute.

\section{Phosphatase activity}

The phosphatase activity was determined according to the method of Tabatabai \& Bremner (1969). Gut extracts from termites $(0.1 \mathrm{~mL})$ were incubated at $37^{\circ} \mathrm{C}$ for $1 \mathrm{~h}$ in a modified universal buffer (MUB) (12.1 g of Tris-hydrochloric aminomethane, 11.6 $\mathrm{g}$ of malic acid, $14.0 \mathrm{~g}$ of citric acid, $6.3 \mathrm{~g}$ of boric acid in water and $488 \mathrm{ml}$ of $0.1 \mathrm{M}$ $\mathrm{NaOH})(\mathrm{pH} 5.0)$ and $0.2 \mathrm{~mL}$ of $115 \mathrm{mM}$-nitrophenylphosphate (p-PNP). The reaction was stopped by the addition of $0.1 \mathrm{~mL}$ of $0.5 \mathrm{M} \mathrm{NaOH}$, and immediate centrifuging for $15 \mathrm{~min}$ at $10,000 \mathrm{rpm}$. The amount of $\mathrm{p}$-nitrophenolreleased from PNP was measured in the supernatant at $405 \mathrm{~nm}$ using p-nitrophenol as standard. The enzyme activity was defined as the amount of enzyme required to liberate $1 \mu \mathrm{g}$ of $\mathrm{p}$-nitrophenol/ $\mathrm{ml} /$ min under assay conditions. 
HOTA, S., SAHOO, S.

\section{Physicochemical properties of termite mound soil}

Soil particle size distribution was determined by the hydrometer method, soil $\mathrm{pH}$ was measured by using the $\mathrm{pH}$ meter. Organic carbon was determined by Walkley and Black wet oxidation method, total $\mathrm{N}$ was determined by the micro Kjeldahl method, Phosphorus content of mound materials was done following the method of Bray \& Kurtz (1945), Na and K were determined by flame photometry.

\section{Statistical analysis}

Statistical Package for Social Sciences (SPSS, 2010) was used for the statistical test. One way ANOVA followed by LSD was used to determine significant differences between means of the parameters obtained from soils and mound materials. Principal Component Analysis was carried out using MINITAB $® 19$ to observe the clustering pattern in three species using different gut enzyme activities and respective mound material characteristics.

\section{RESULTS}

\section{Enzyme activities}

$\alpha$-amylase activity, cellulase activity, xylanase activity ( $\mu \mathrm{g}$ glucose $/ \mathrm{ml}$ of enzyme extract/ $\mathrm{min}$ ) and phosphatase activity (p-nitrophenol/ $\mathrm{ml} / \mathrm{min}$ ) of three different termite guts (Odontotermes brunneus, Odontotermes obesus and Odontotermes feae) has been illustrated in (Table. 1) along with one way ANOVA and LSD values.

\section{Physico-chemical properties of nest soil}

The textural composition of respective mounds from which the termites were collected indicated highest clay content of $12.93 \%$ in subterranean nest soil of $O$. obesus followed by the clay content of $12.02 \%$ in epigeous mound soil of $O$ brunneus, and then that of $O$. feae arboreal nest soil $(9.64 \%)$. The percentage of sand was highest in the arboreal nest soil (89.36\%), followed by that of epigeous nest soil $84.98 \%$, and that of subterranean nest soil ( $80.27 \%$ ). Water holding capacity (WHC in \%) of around $25 \%$ was recorded in subterranean nest soil as well as that of epigeous nest soil. The arboreal nests showed the WHC (\%) of $21 \%$. The subterranean nest soil showed a pH which was more acidic ( $5.95 \pm 0.736)$ than that of epigeous $(6.858 \pm 0.375)$ and arboreal nest soil $(6.317 \pm 0.264)$ and the difference was significant at $p<0.05\left(F_{2,15}=4.998\right)$.

The highest organic carbon ( $\mathrm{OC}$ in $\mathrm{g} \%$ ) content of mound material (Table. 2) was found in subterranean termites as compared to epigeous and arboreal nest soil. Similarly total nitrogen (TN), available phosphorus (AP), available potassium (AK), water holding capacity (WHC), and pH showed a significant difference between three types of nest soil.

The LSD tests demonstrate a significant difference in the average value of TN, AP, AK in different termite nest soil. However, Average WHC of O. bruneus and O.obesus nest soil showed significant difference with that of $O$. feae nest soil, but not among themselves. Similarly, the average $\mathrm{pH}$ value of $\mathrm{O}$. bruneus and $\mathrm{O}$. feae nest soil showed a significant difference with that of $O$. obesus, but not among themselves. 
A Comparative Study of Gut Enzymes and Nest Materials of Three Mound Building Termites

To find out the correlation between the termite enzyme activities, and their respective nest soil multiple correlations were conducted using SPSS 16 (Table. 3). Amylase, xylanase, cellulase, and phosphatase activities of termites showed a significant correlation with the physicochemical properties of mound materials like WHC, OC, TN, AK etc.

Table 1. Gut enzyme activities of different termite species.

\begin{tabular}{|c|c|c|c|c|c|}
\hline \multirow{2}{*}{$\begin{array}{l}\text { Enzyme } \\
\text { activities }\end{array}$} & \multicolumn{3}{|c|}{ Termite Species } & \multirow{2}{*}{$\begin{array}{c}\text { One way } \\
\text { ANOVA } \\
(F), \\
\text { Critical } \\
\text { value of F = } \\
3.68232\end{array}$} & \multirow{2}{*}{$\begin{array}{c}\text { LSD } \\
(p \leq 0.05)\end{array}$} \\
\hline & O. bruneus & O. obesus & O. feae & & \\
\hline aAmylase & $\begin{array}{l}0.945 \pm \\
0.127^{a}\end{array}$ & $0.62 \pm 0.031^{b}$ & $\begin{array}{l}0.608 \pm \\
0.166^{b}\end{array}$ & $14.670^{* * *}$ & 0.325 \\
\hline Cellulase & $\begin{array}{l}0.433 \pm \\
0.038^{a}\end{array}$ & $0.82 \pm 0.061^{b}$ & $\begin{array}{l}0.408 \pm \\
0.055^{a}\end{array}$ & $116.881^{* * *}$ & 0.387 \\
\hline Xylanase & $1.083 \pm 0.179^{a}$ & $\begin{array}{l}1.443 \pm \\
0.037^{b}\end{array}$ & $\begin{array}{l}0.807 \pm \\
0.115^{b c}\end{array}$ & $39.198^{* * *}$ & 0.36000 \\
\hline Phosphatase & $\begin{array}{l}8.003 \pm \\
0.864^{a}\end{array}$ & $\begin{array}{l}10.143 \pm \\
0.606^{\mathrm{b}}\end{array}$ & $\begin{array}{l}7.787 \pm \\
0.749^{a}\end{array}$ & $18.231^{* * *}$ & 2.14 \\
\hline
\end{tabular}

${ }^{* * *} p<0.001, F=$ values of one way ANOVA between enzyme activities of different termites, values in the same row with different alphabet were significantly different by LSD $(p<0.05)$.

Table 2. Physico-chemical properties of nest soils from O. bruneus, O. obesus, and O. feae termites.

\begin{tabular}{|c|c|c|c|c|c|}
\hline \multirow{2}{*}{$\begin{array}{l}\text { Physico- } \\
\text { chemical } \\
\text { parameters }\end{array}$} & \multicolumn{3}{|c|}{ Termite Nest Soil } & \multirow{2}{*}{$\begin{array}{c}\text { One way ANOVA }(\mathrm{F}) \text {, } \\
\text { Critical value of } \mathrm{F}= \\
3.68232\end{array}$} & \multirow{2}{*}{$\underset{(p<0.05)}{\text { LSD }}$} \\
\hline & O. bruneuS & O. obesus & O. feae & & \\
\hline OC & $0.583 \pm 0.01^{a}$ & $1.695 \pm 0.12^{b}$ & $0.583 \pm 0.014^{a}$ & $498.196^{* * *}$ & 1.11167 \\
\hline TN & $1.468 \pm 0.039^{a}$ & $1.84 \pm 0.119^{b}$ & $1.378 \pm 0.124^{\text {bc }}$ & $34.741^{* * *}$ & 0.37167 \\
\hline AP & $0.693 \pm 0.051^{a}$ & $0.882 \pm 0.025^{b}$ & $0.78 \pm 0.033^{\mathrm{bc}}$ & $36.658^{* * *}$ & 0.18833 \\
\hline AK & $342.167 \pm 78.062^{\mathrm{a}}$ & $1138.667 \pm 93.607^{b}$ & $181.33 \pm 5.428^{\text {bc }}$ & $317.779^{* \star *}$ & 796.5 \\
\hline WHC & $24.295 \pm 3.133^{\mathrm{a}}$ & $25.25 \pm 2.518^{\mathrm{a}}$ & $20.275 \pm 3.228^{b}$ & $4.721^{*}$ & 4.975 \\
\hline $\mathrm{pH}$ & $6.858 \pm 0.375^{\mathrm{a}}$ & $5.95 \pm 0.736^{b}$ & $6.317 \pm 0.264^{a}$ & $4.998^{*}$ & 0.908 \\
\hline
\end{tabular}

${ }^{*} p<0.05,{ }^{* * *} p<0.001, F=$ values of one way ANOVA between enzyme activities of different termites, values in the same row with different alphabet were significantly different by LSD $(p<0.05)$.

Table 3. Correlation between gut enzymes and soil biochemical characteristics.

\begin{tabular}{|c|c|c|c|c|c|c|c|c|c|c|}
\hline & $\mathrm{OC}$ & TN & AP & AK & $\mathrm{pH}$ & WHC & Amylase & Xylanase & Cellulase & Phosphatase \\
\hline$O C$ & 1 & $.930 *$ & $.841^{\circ}$ & $.987^{\prime \prime}$ & $-.839^{\circ}$ & .559 & $.847^{\circ}$ & $.829^{\circ}$ & $.754^{\circ}$ & $.948^{* \prime}$ \\
\hline TN & $.930^{\circ}$ & 1 & .639 & $.955^{\prime \prime}$ & -.672 & $.757^{\circ}$ & .638 & $.932^{\prime \prime}$ & $.808^{\circ}$ & $.948^{\prime \prime}$ \\
\hline $\mathrm{AP}$ & $.841^{\circ}$ & .639 & 1 & $.757^{\circ}$ & $-.832^{\circ}$ & .129 & $.801^{\circ}$ & .402 & .604 & $.819^{\star}$ \\
\hline AK & $.987^{\prime \prime}$ & $.955^{\prime \prime}$ & $.757^{\circ}$ & 1 & $-.792^{\circ}$ & .629 & $.800^{\circ}$ & $.884^{\prime \prime}$ & $.737^{\circ}$ & $.890^{* \prime}$ \\
\hline $\mathrm{pH}$ & $-839^{\circ}$ & -.672 & $-.832^{\circ}$ & $-.792^{\circ}$ & 1 & -.072 & -.720 & -.580 & -.332 & -.73 \\
\hline WHC & .559 & $.757^{\circ}$ & .129 & .629 & -.072 & 1 & .382 & $.816^{\circ}$ & $.806^{\circ}$ & .055 \\
\hline Amylase & $.847^{\circ}$ & .638 & $.801^{\circ}$ & $.800^{\circ}$ & -.720 & .382 & 1 & .587 & .635 & -.057 \\
\hline Xylanase & $.829^{\circ}$ & $.932^{\prime \prime}$ & .402 & .884 & -.580 & $.816^{\circ}$ & .587 & 1 & .678 & $.947^{* \prime}$ \\
\hline Cellulase & $.754^{\circ}$ & $.808^{\circ}$ & .604 & $.737^{\circ}$ & -.332 & $.806^{\circ}$ & .635 & .678 & 1 & $.876^{\circ}$ \\
\hline Phosphatase & $.948^{\prime \prime}$ & $.948^{\prime \prime}$ & $.819^{\circ}$ & $.890^{\prime \prime}$ & -.73 & .055 & -.057 & $.947^{\prime \prime}$ & $.876^{\circ}$ & 1 \\
\hline
\end{tabular}

${ }^{*}$ Correlation is significant at the 0.05 level (2-tailed). ${ }^{* *}$ Correlation is significant at the 0.01 level (2-tailed). (OC: Organic Carbon (g\%), TN: Total Nitrogen (g\%), AP: Available phosphorus (g\%), AK: Available Potassium (g\%), WHC: Water Holding Capacity (g\%), Amylase, Cellulase, Xylanase activity ( $\mu \mathrm{g}$ glucose/ $\mathrm{ml}$ gut extract/min) and Phosphatase ( $\mu \mathrm{g}$ of $\mathrm{p}$-nitrophenol/ $\mathrm{ml}$ gut extract/ min). 
HOTA, S., SAHOO, S.

\section{CONCLUSIONS AND DISCUSSION}

Carbon in plant biomass is the largest reservoir on Earth and the extensive verity of organisms is using this carbon as the main food source. However, most of the animals are unable to assimilate plant biomass, due to the complex architecture of the plant cell wall (Pauly \& Keegstra, 2008). The plant cell wall is primarily composed of cellulose, hemicellulose, pectin, and lignin (McNeil, Darvill, Fry, \& Albersheim, 1984). Different factors that cause the complexity of termite nests are by virtue of their social organization, feeding habit, morphology and behavior of different casts. Moreover, environmental characteristics attribute to wide range of variations. There are some termite species that create simple nests and some build complex nests which represent a large architecture (Petr, Jiří, František, \& Tomáš, 2013). The decomposition of any wood substrate is a result of symbiotic associations between subterranean termites with other microorganisms, especially fungi (Resh \& Cardé, 2009).

Termite digestomes are found to be associated with as much as 250 different species of microorganisms (Nadin, 2007). However, not all of them are cellulolytic microorganisms. These microorganisms are specifically degrading specific components of the plant structures resulting in different end products. According to previous reports, termites could potentially decompose lignocelluloses within a day by degrading $74-99 \%$ of the cellulose, $65-87 \%$ of the hemicellulose, as well as $5-83 \%$ of the lignin producing weak acids and simple sugars (König, Fröhlich, \& Hertel, 2006).

We observed the highest enzyme activities by subterranean species $O$. obesus associated with fungus garden in comparison to epigeous $O$. bruneus and tree-dwelling $O$. feae species. The highest OC, TN, AP, AK and higher clay\%, WHC\% in subterranean termite mound soil as compared to the epigeous, arboreal mound are likely to be contributed by the combined action of foraging materials available and the enzyme activities of the termites residing in the mound to convert these materials to available nutrients. Termites that excavate hardwood or soft wet wood (arboreal termites) cut out tunnels and then plaster them with faces that are heavily fibrous with plastic texture. It is reported that they even utilize sand grains for partitioning and cementing that with their faeces to create a thick fabric of $2 \mathrm{~mm}$ (Lee \& Wood, 1971). Menichetti et al (2014) have reported that the grazing activity and nutrient flux into the subterranean mound material is more in comparison to the epigeal part of the mound. This might be the reason for a significantly high enzyme, both cellulase and xylanase activities of subterranean termite in comparison to those collected from epigeal parts of large roadside nests. The salivary glands and the upper gut region secrete amylase enzymes that do not contain microbes as reported by O'Brien \&Slaytor (1982). Most termites use soil, together with saliva and faeces, to construct their nests (Wood, 1988), the reason for which we observed the highest amylase activity in $O$. bruneus collected from large epigeous mounds from the roadside.

Principal Component Analysis was carried out considering the data of Amylase, Cellulase, Xylanase, Phosphatase activities of epigeous Odontotermes brunneus (A), subterranean Odontotermes obesus (B) and arboreal Odontotermes feae (C) termite guts and OC, TN, AP, AK, WHC, pH of respective termite nest soil (Fig. 5). Termites 
A Comparative Study of Gut Enzymes and Nest Materials of Three Mound Building Termites

that have similar on the basis of their nest characteristics are clustered together and we obtained 3 clusters of three termite species. The characteristics that have heavily influenced PC1 strongly, differentiates Odontotermes obesus (B) from other two species and the characteristics that heavily influenced $P C 2$ segregated Odontotermes brunneus (A) from Odontotermes feae (C).

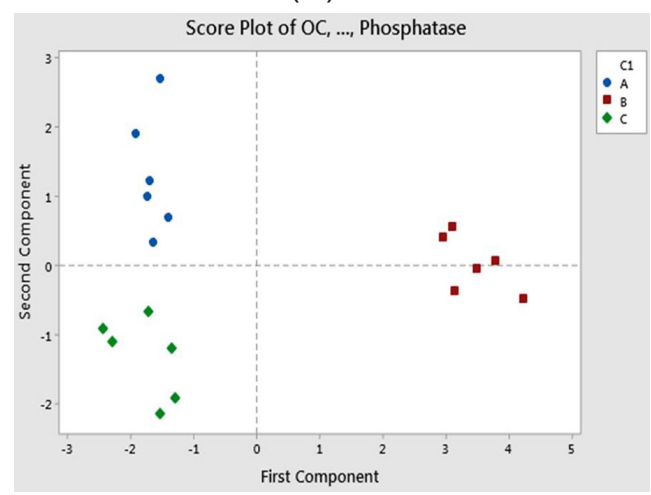

Fig. 5. PCA of enzyme activities in of three termite species and physicochemical properties of respective mound materials: red colour, subterranean species $O$. obesus; blue, epigeous $O$. bruneus; green colour, tree dwelling O. feae species.

This study indicated and statistically proved that different builder species cause significant variation in mound structures and physicochemical properties as well. Hence the study will help in the effective usage of suitable termite species and respective mound soil material in an eco-friendly manner to ensure environmental sustainability.

\section{ACKNOWLEDGEMENTS}

The authors gratefully acknowledge the Head, School of Life Sciences, Sambalpur University, Odisha for providing the necessary research facilities.

\section{REFERENCES}

Beg, Q.K., Kapoor, M., Mahajan, L., \& Hoondal, G.S. (2001). Microbialxylanases and their industrial applications: A review. Applied Microbiology and Biotechnology, 56(3-4), 326-338.

Bernfeld, P. (1955). Amylases, alpha and beta. Methods in Enzymology, 1, 149-158.

Bray, R.H. \& Kurtz, L.T. (1945). Determination of total organic and available forms of phosphorus in soils. Soil Science, 59, 39-45.

Brune, A. (2014). Symbiotic digestion of lignocellulose in termite guts. Nature Reviews Microbiology, 12, 168-180.

District Administration Sambalpur (2021, October, 17). Coordinates $\left(21.466^{\circ} \mathrm{N}, 83.983^{\circ} \mathrm{E}\right)$. Retrieved from https://en.wikipedia.org/wiki/Sambalpur_district\#/media/File:India_Odisha_Sambalpur_district.svg.

Enagbonma, B.J. \& Babalola, O.O. (2019). Potentials of termite mound soil bacteria in ecosystem engineering for sustainable agriculture. Annals of Microbiology, 69, 211-219.

Sahu, C., Nayak, H.N., \& Sahu, S.K. (2020). Carbon sequestration potential of trees in an urban area: a case study of sambalpur town in eastern india. Fresenius Environmental Bulletin, 29, 8757-8766. 
Keyholl, Inc. (2001, October, 17). Map Courtesy: Google Earth. Retrieved from https://earth.google.com/ web/search/Sambalpur+University,+Jyoti+Vihar,+Burla,+Odisha/@21.47616833,83.8827404,177. 88349303a,3027.4930729d,35y,0h,0t,0r/data=CigiJgokCR6EBmvPejVAEarts_QieTVAGVB8DDPfFRAldYuPt7v91RA

König, H., Fröhlich, J., \& Hertel, H. (2006). Diversity and lignocellulolytic activities of cultured microorganisms. In König, H. \& Varma, A. (Ed.). Intestinal microorganisms of termites and other invertebrates (pp. 271-301), Soil Biology, Springer, Berlin, Heidelberg.

Lee, K.E. \& Wood, T.G. (1971). Termites and soils. Academic Press, London, New York.

Lima, T.A., Pontual, E.V., Dornelles, L.P., Amorim, P.K., Araújo, R., Coelho, L.C.B.B., Napoleão, T.H., \& Paiva, P.M.G. (2014). Digestive enzymes from workers and soldiers of termite Nasutitermes corniger. Comparative Biochemistry and Physiology, Part B, 176, 1-8.

McNeil, M., Darvill, A.G., Fry, S.C., \& Albersheim, P. (1984). Structure and function of the primary cell walls of plants. Annual Review of Biochemistry, 53, 625-663.

Mehta, S.P. (1996). Survey of India Maps, 1st ed, Government of India.

Menichetti, L., Landi, L., Nannipieri, P., Kätterer, T., Kirchmann, H., \& Renella, G. (2014). Chemical properties and biochemical activity of colonized and abandoned litter-feeding termite (Macrotermes spp.) mounds in Chromic Cambisol Area on the Borana plateau, Ethiopia. Pedosphere, 24, 399-407.

Nadin, E., (2007). For the love of termites. Engineering Science, 2, 24-31.

$\mathrm{Ni}$, J. \& Tokuda, G. (2013). Lignocellulose-degrading enzymes from termites and their symbiotic microbiota. Biotechnology Advances, 31(6), 838-50.

O'Brien, R.W. \& Slaytor, M. (1982). Role of microorganisms in the metabolism of termites. Australian Journal of Biological Sciences, 35, 239-262.

Pauly, M. \& Keegstra, K. (2008). Cell-wall carbohydrates and their modification as a resource for biofuels. The Plant Journal: for Cell and Molecular Biology, 54, 559-568.

Petr, P., Jiří, B., František, Š., \& Tomáš, O. (2013). Investigation of subterranean termites nest material composition, structure and properties. In Yitzhak, M. (Ed.), Materials science-advanced topics, IntechOpen, Doi: 10.5772/55145 (pp. 519-549).

Resh, V.H., Cardé, R.T. (2009). Encyclopedia of insects, 2nd ed., Academic press, Elsevier, United States.

Schäfer, A., Konra, D.R., Kuhnigk, T., Kämpfer, P., Hertel, H., \& König, H. (1996). Hemicellulose-degrading bacteria and yeasts from the termite gut. Journal of Applied Ecology, 80, 471-478.

Slaytor, M. (2000). Energy metabolism in the termite and its gut microbiota. In Abe, T., Bignell, D.E., \& Higashi, M. (Eds.). Termites: evolution, sociality, symbioses, ecology (pp. 307-332). Springer, Dordrecht.

Smith, J.A. (2007). Cellulolytic and xylanolytic gut enzyme activity patterns in Major Subterranean termite pests. Phd Thesis, University of Florida, Gainesville, Florida.

Tabatabai, M.A. \& Bremner, J.M. (1969). Use of p-nitrophenyl phosphate for assay of soil phosphatase activity. Soil Biology and Biochemistry, 1(4), 301-307

Varma, A., Kolli, B.K., Paul, J., Saxena, S., \& Konig, H. (1994). Lignocellulose degradation by microorganisms from termite hills and termite guts: A survey on the present state of art. Federation of European Microbiological Societies Microbiology Reviews, 15:9-28

Waller, D.A. \& La Fage, J.P. (1987). Nutritional ecology of termites. In Slansky, Jr. F. \& Rodriguez, J.G. (Eds.). Nutritional ecology of insects, mites, spiders and related invertebrates. (pp. 487-532). A Wiley-Interscience Publication, New York.

Wood, T.G. (1988). Termites and the soil environment. Biology and Fertility of Soils, 6, 228-236. 